\title{
Proximate Composition of Minor Millets from Cold Semi-Arid Regions
}

\author{
Madhulika Esther Prasad, Ishita Joshi, Navin Kumar, Pankaj Gautam, Jyoti Chhabra
}

\begin{abstract}
The nutritional importance of minor millets growing in geographically and environmentally isolated semi-arid regions remains largely unexplored, which has led to it being underutilized for diet diversification. In this study, the proximate composition of three species of minor millets, namely, Barnyard millet (Echinochloa frumentacea),Finger millet (Eleusine coracana) and Foxtail millet(Setaria italica), grown in traditional millet cultivating regions (cold semi-arid) of the Himalayan range, have been analyzed. Two high altitude locations of contrasting cold temperatures in this region were selected for analysis. Dehradun which exhibits a temperature of $25-27^{\circ} \mathrm{C}$, is located at 640 masl. (Meters Above Sea Level) in Uttarakhand West $(U W)$, whereas, the second location, Pithoragarh which exhibits a temperature of $15-17^{\circ} \mathrm{C}$ is located at 1514 masl. in Uttarakhand East (UE). The results of this study record a 30.75 percent increase in average protein content of Barnyard millet grains when the same seed stock was grown at the second region of lower temperature, i.e. Pithoragarh $\left(15-17^{\circ} \mathrm{C}\right)$, as compared to Dehradun $\left(15-17^{\circ} \mathrm{C}\right)$. A 42.66 percent increase in average fat content was also recorded for Barnyard millet grains when grown at Pithoragarh $\left(15-17^{\circ} \mathrm{C}\right)$. The two other millet species, Finger millet and Foxtail millet, did not record significant differences in protein and fat contents, however, Foxtail millet displayed marginally increased levels of sodium and potassium. In contrast to the other components analyzed, Total Dietary Fiber (TDF) was found to decrease with growth at the comparatively colder location of Pithoragarh. A 36.71 percent decrease in TDF content was recorded for Barnyard millet, whereas, a 19.25 percent decrease was recorded for Finger millet. Foxtail millet displayed a marginal decrease of only 5.3 percent in TDF content with growth at Pithoragarh. Starch concentration and moisture content for all three species was also studied, but did not record any notable differences due to growth at the colder location of Pithoragarh. The results here indicate an important role of cold temperature and high altitude in regulating the proximate composition of minor millet grains. Studies which explore the proximate composition of millet cultivars in such geographically and environmentally distinct millet growing regions, may reveal new information regarding the nutritional importance of minor millets, and the ideal conditions of growth for maximum nutritional benefit.
\end{abstract}

Keywords: Millets, Proximate Composition, Cold Temperature, High Altitude

Revised Manuscript Received on October 02, 2019.

*Corresponding Author

Madhulika Esther Prasad*, Department of Biotechnology, Graphic Era (deemed to be University), Dehradun, India, Email address: esthermadhu.bio@geu.ac.in, esthermadhu@gmail.com.

Ishita Joshi, Department of Food Science \& Technology, RMIT University, Melbourne, Australia. Email address: ishitajoshi94@yahoo.com Navin Kumar, Department of Biotechnology, Graphic Era (Deemed to be University), Dehradun, India, Email address:navinkumar.bt@geu.ac.in, navinbajpai@gmail.com

Jyoti Chhabra Department of Fashion Designing, Graphic Era Hill University Dehradun

Pankaj Gautam, Department of Biotechnology, Graphic Era (Deemed to be University), Dehradun, India, Email address: pankajgautam.bt@geu.ac.in, gautampankaj76@gmail.com

\section{INTRODUCTION}

Millets are nutritionally superior, small cereal grains belonging to the grass family Poaceae [1].

They are climate-compliant rain-fed crops which possess an excellent ability to withstand extremesof temperature, and are thus grown in both the hot and cold semi-arid regions of the developing world [2,3].

They are an excellent source of protein and energy coupled with various micronutrients, such as Zinc, Iron, Sodium, Potassium, Calcium, Magnesium, B-vitamins, dietary fiber and essential amino acids [4]. Along with nutrients and minerals they are also rich in phytochemicals such as antioxidants, polyphenols, polycyanins, flavonoids and polysterols [5]. Millets have numerous health benefits which range from improving the immune system to prevention of age-onset diseases. Their low glycemic index property reduces post-prandial blood glucose level [6].

Millets species are primarily divided into two categories, the major millets comprising of Pearl millet (Pennisetum glaucum) and Sorghum (Sorghum bicolor), and the minor millets comprising of Foxtail millet (Setaria italica), Proso millet (Panicum miliaceum), Finger millet (Eleusine coracana), Kodo millet (Paspalum scrobiculatum), Barynard millet (Echinochloa frumentacea) and Little millet (Panicum sumatrense) [4].

Minor millets are subsistence crops which require minimal inputs during cultivation, have shorter growing seasons of 70-90 days, and possess smaller size of grains [7]. In spite of their sturdiness and long storage life, minor millets have received very less attention, owing to lack of processing technologies for decortication, poor financial returns and most importantly, due to ignorance of their rich nutritional profile [8]. With high-yielding crops such as wheat and rice overshadowing nutritional importance, studies on the nutritional composition of millet grains from geographically and environmentally distinct millet-growing regions is required.

This study presents the proximate composition of three minor millet species from two traditionally milletgrowing, cold semi-arid regions located in the higher altitudes of the Himalayan range. Comparisons have been drawn between the proximate composition of millets grown in these two regions of varying cold temperatures, Dehradun $\left(25^{\circ} \mathrm{C}\right)$ and Pithoragarh $\left(15^{\circ} \mathrm{C}\right)$.

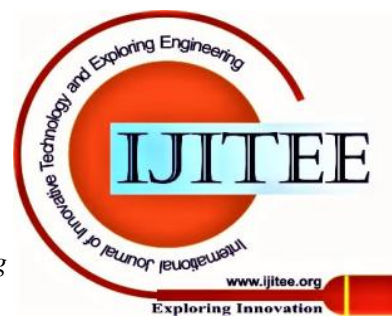




\section{Proximate Composition of Minor Millets from Cold Semi-Arid Regions}

\section{MATERIALS \& METHODS}

Three species of millets, namely, Barnyard millet (Echinochloa frumentacea), Finger millet (Eleusine coracana) and Foxtail millet (Setaria italica), were grown at two different high altitude regions, exhibiting an altitude difference of 874 masl. (Meters Above Sea Level), and situated in the Uttarakhand province of India. These two regions with similar cold semi-arid climate, but particularly variant cold temperatures, included Dehradun, at 640 masl. in Uttarakhand West (UW), with a temperature of $25-27^{\circ} \mathrm{C}$, and Pithoragarh, at 1514 masl. in Uttarakhand East (UE), with a temperature of $15-17^{\circ} \mathrm{C}$ during the Kharif season.

Grain samples representing the populations of the three millet species were harvested, cleaned using distilled water, air-dried for a week, and stored in airtight polypropylene bags at $-20^{\circ} \mathrm{C}$ until further analysis. For analyses, the grains were hand pounded in a pestle and mortar to remove the husks and pericarp, ground into coarse flour using a blender, and passed through a 60 mesh sieve to remove larger particles [9].

\section{B. Analysis of Proximate Composition} analysed using Association of Official Analytical Chemists (AOAC) procedures [10,11]. Nutrient analyses included determination of average protein content $(\%)$, fat content (\%), Total Dietary Fiber (\%) (TDF), starch concentration $(\mathrm{mg} / \mathrm{ml})$ and moisture content (\%). Mineral analysis included determination of the level of sodium $(\mathrm{g} / 100 \mathrm{~g})$ and potassium $(\mathrm{g} / 100 \mathrm{~g})$. All the chemicals, reagents and enzymes used were of analytical grade. Proximate analysis of each component was carried out in triplicates, with mean $( \pm)$ values used for comparative study.

\section{- Protein}

Protein (Nitrogen x 6.25) content was determined using the Kjeldahl digestion and distillation method (AOAC method 2001.11) [12]. Following protein digestion of the sample with $95 \%$ Sulphuric acid (Nitrogen-free) in a protein digester (Kjeldatherm digestion block, Gerhardt $\mathrm{GmbH} \&$ Co. KG, Germany), the digest was distilled using Boric acid and $\mathrm{NaOH}$ solutions. The protein concentration was then estimated colorimetrically using titration with standardized $\mathrm{HCl}$. solution containing THAM (Tris Hydroxymethyl Aminomethane).

- Fat

Total fat was determined using the Soxhlet extraction method [13]. Millet flour sample (3g) was added to a thimble, placed in a Soxhlet apparatus and extracted for 7 hours with Petroleum Ether $\left(60-80^{\circ} \mathrm{C}\right)$ (AOAC method 930.09) [14]. Following extraction, the thimbles were airdried overnight, and then in a hot-air oven at $105^{\circ} \mathrm{C}$ for 24 hours. The loss in weight was measured at time periods indicated by the protocol [15]. An AOAC optimized formulae was used to derive the percentage of fat by calculating the loss in weight of the sample following extraction, and also by correcting for moisture content using a hot-air oven.

\section{Total Dietary Fiber}

\section{A. Collection and Preparation of Millet Grain Samples}

Proximate composition of the flour samples was

For Total Dietary Fiber (TDF) determination, an enzymatic-gravimetric assay kit (Sigma Aldrich- TDF100A) was employed (AOAC method 985.29) [16]. Following gelatinization with $\alpha$-amylase, the protein and starch in the sample were removed by enzymatic digestion with protease and amyloglucosidase. The percentage of total dietary fibre was derived from the weight of the residue, from which the weight of protein and ash had been deducted. The protein here was determined using the Kjeldahl procedure, and ash was determined using a muffle furnace.

\section{- Mineral Analysis}

Sodium and Potassium levels in the flour samples were determined using a Flame Photometer. (Gallenkamp Flame Photometer, UK) (AOAC method 969.23) [17]. Samples for mineral analysis were prepared by incinerating $2 \mathrm{~g}$ flour sample in crucibles by placing in a muffle furnace at $550^{\circ} \mathrm{C}$ to form ash. The ash obtained was digested in concentrated $\mathrm{HNO}_{3}$ to form a clear solution, which was then used for mineral analysis in a flame photometer [18].

\section{- $\quad$ Starch}

The starch concentration in starch solutions of the millet flour samples was estimated using Anthrone's reagent [19]. Starch solutions were prepared by precipitating starch from the flour samples $(0.1 \mathrm{~g}-0.5 \mathrm{~g})$ using hot $80 \%$ ethanol, and extracted from the resulting residue using 52\% Perchloric acid. The concentration of starch in the solution obtained was determined colorimetrically with Anthrone's reagent. The final starch concentration was calculated on the basis of a standard graph of glucose concentration values at $630 \mathrm{~nm}$ using a UV spectrophotometer (UV-Vis-NIR Spectrophotometer, UV-3600 Plus - Shimadzu).

\section{- Moisture}

Moisture content was determined using a hot-air oven (AOAC method 935.29) [20]. For this analysis, millet grains were dried to a constant weight at $105^{\circ} \mathrm{C}$ in a hot-air oven for $\sim 8$ hours and then ground to a fine powder, before passing it through a $0.3 \mathrm{~mm}$ sieve [15]. The flour samples $(3 \mathrm{~g})$ were placed in crucibles and weighed before drying for 24 hours. in a hot-air oven at $105^{\circ} \mathrm{C}$. The crucibles were also weighed before addition of the flour samples.

\section{RESULTS\& DISCUSSION}

A proximate analysis of the grain samples of three different millet species, Barnyard millet (Echinochloa frumentacea), Finger millet (Eleusine coracana) and Foxtail millet (Setaria italica), grown at cold semi-arid regions of the Himalayas in Uttarakhand, was carried out using biochemical assays to determine any differences in grain composition due to growth at cold temperatures. The three millet species were compared between two semi-arid regions of varying cold temperatures in the state of Uttarakhand. Dehradun which has a temperature of $15^{\circ} \mathrm{C}-$ $17^{\circ} \mathrm{C}$ during the Kharif growing season, and Pithoragarh, which has a temperature of $25^{\circ} \mathrm{C}-27^{\circ} \mathrm{C}$, were selected for 
comparative analysis. Macronutrients such as starch and protein, and micronutrients such as fat, sodium, potassium and total dietary fibre were determined in populations of all three millet species grown at Dehradun and Pithoragarh.

The proximate analyses exhibit an increase in average protein content and average fat content for the Barnyard millet species only. The other two millet species, Foxtail millet and Finger millet, exhibited negligible difference in proximate composition when grown at the higher altitude, cold semi-arid region of Pithoragarh (15$17^{\circ} \mathrm{C}$ ). Nonetheless, Foxtail millet exhibited marginal increase in sodium and potassium. In contrast, the percentage of Total dietary fiber was found to decrease in all three species with growth at Pithoragarh. Detailed observations of the analytical assays are described below, and a summary of the proximate composition given in table 1. Grains from the same seed stock were used for growth in both regions. All biochemical analyses, as well as ash and moisture content were determined using AOAC (Association of Official Analytical Chemists) methods as previously carried out on millets $[18,11]$.

\section{A. Protein Content}

Proteins constitute the second most abundant macronutrient in millet grains after starch [21]. The minor millets are known to contain 19-33\% less protein than the major millets [22]. Protein content also varies with external factors such as environmental and agronomic conditions, which include water availability and soil temperature [23]. In this study, soil temperature is particularly important as comparisons have been drawn between two cold semi-arid regions exhibiting temperature differences of approximately $12-15^{\circ} \mathrm{C}$.

Here, the average protein content estimated by the Kjeldahl digestion and distillation procedure, recorded a 30.75 percent increase in Barnyard millet grains grown at $15-17^{\circ} \mathrm{C}$ in Pithoragarh (1514 Meters Above Sea Level (masl.) in Uttarakhand East), as compared to the same variety and stock of Barnyard millet grains grown at Dehradun, 640 masl., which is approximately $10^{\circ} \mathrm{C}$ warmer $\left(25-27^{\circ} \mathrm{C}\right)$ (Fig.1). When compared to previous studies reporting protein content from further warmer regions (lower altitude) of semi-arid climate [24], the growth at Dehradun in this study shows a $11.16 \%$ increase, whereas the growth at Pithoragarh displays a $38.48 \%$ increase in protein content.

This data indicates that the exposure to cold temperatures during growth of millets may have a role to play in exhibiting higher protein content, and thus regulating the final proximate composition of the Barnyard millet grains in this study. Differences in weather conditions, especially, the influence of temperature have been known to play important roles in regulating grain protein concentration. For example, in wheat, variations in weather conditions during field growth have been known to induce differences in the protein concentration of grains of the same genotype [25]. Here, response to temperature was considered as one of the factors that regulated the concentration of protein. In another study, low temperature was found to induce accumulation of protein in root meristems and calluses of Winter wheat[26].
The two other millet species in this study, Foxtail millet and Finger millet exhibited marginal differences in average protein content (Fig. 1) due to growth at Pithoragarh $\left(17^{\circ} \mathrm{C}, 1514\right.$ masl.) when compared to growth at Dehradun $\left(25-27{ }^{\circ} \mathrm{C}, 640\right.$ masl.). Comparative data on millets from warmer regions (lower altitude), depict protein content in Finger millets to range from 5.6\% to $11.8 \%$ [27,28], and that in Foxtail millet to be $12.2 \%$ [8], as evident in the data depicted in this study, where Finger millet protein content ranged from $6.57 \%$ (Dehradun) to $7.30 \%$ (Pithoragarh), whereas, the Foxtail millet protein content ranged from $11.97 \%$ (Dehradun) to $13.40 \%$ (Pithoragarh).

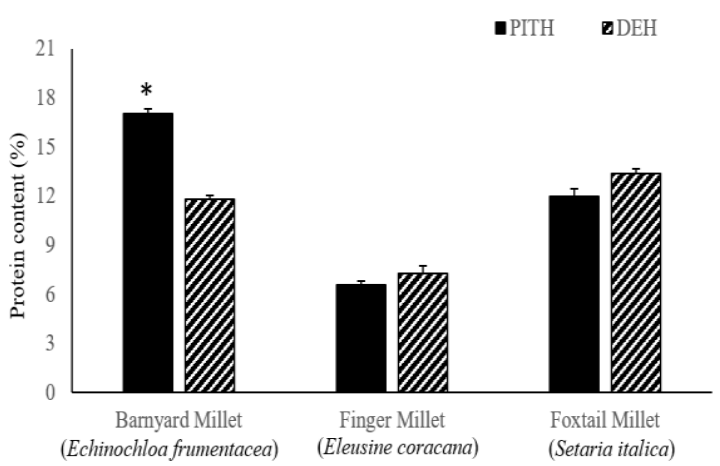

Fig.1. Protein content (\%) of three minor millet species grown in Dehradun (DEH) and Pithoragarh (PITH) (cold semi-arid regions of Uttarakhand) determined by Kjeldahl Digestion and Distillation. The graph represents Mean $\pm \mathrm{SE}$ of triplicates. *Significantly different $(\mathbf{p}<0.05)$.

\section{B. Fat Content}

Fat content was determined by the Soxhlet Extraction procedure and the percentage of fat calculated by the formulae:

$\%$ Fat $=(\%$ Fat $+\%$ Moisture $)-(\%$ Moisture $)$

- $\quad$ \% Fat $+\%$ Moisture)

$=[($ Initial wt of sample + thimble + glasswool $)-($ Finalwt of sample+thimble+glasswool)] x100

[(Wt of wet sample + thimble $)-($ Wt of thimble $)]$

- \% Moisture

$=[(\mathrm{Wt}$ of wet sample + pan $)-(\mathrm{Wt}$ of dried sample + pan $)] \mathrm{x}$ 100

$[(\mathrm{Wt}$ of wet sample + pan $)-(\mathrm{Wt}$ of pan $)]$

The fat content of Barnyard millet grains in previous studies has been found to range from $3.6 \%$ to $3.8 \%$ [8,24]. In this study, the average fat content of Barnyard millet grains grown in Dehradun (640 masl.) was found to be $2.97 \%$, but a 42.66 percent increase in fat content compared to Dehradun, was recorded in Barnyard millet grains grown at Pithoragarh (1514 masl.), which exhibited an average fat content of $5.18 \%$ (Fig.2).

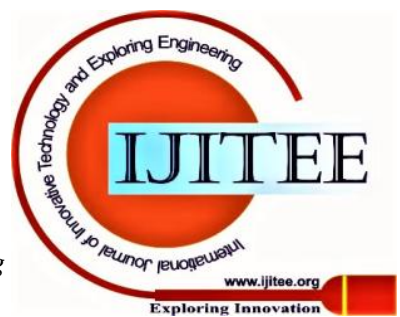




\section{Proximate Composition of Minor Millets from Cold Semi-Arid Regions}

Pithoragarh exhibits a temperature of $\sim 17^{\circ} \mathrm{C}$ during the Kharif season, as compared to Dehradun $\left(25-27^{\circ} \mathrm{C}\right)$. This data shows that fat content, similar to protein content, followed an increasing trend when grains were exposed to cold temperatures during growth. The two other species, Finger millet and Foxtail millet, did not exhibit significant differences in average fat content when grown at Dehradun (640 masl.) compared to Pithoragarh (1514 masl.). The Finger millet and Foxtail millet populations in this study also exhibited fat content similar to comparative data from literature $[8,24]$.

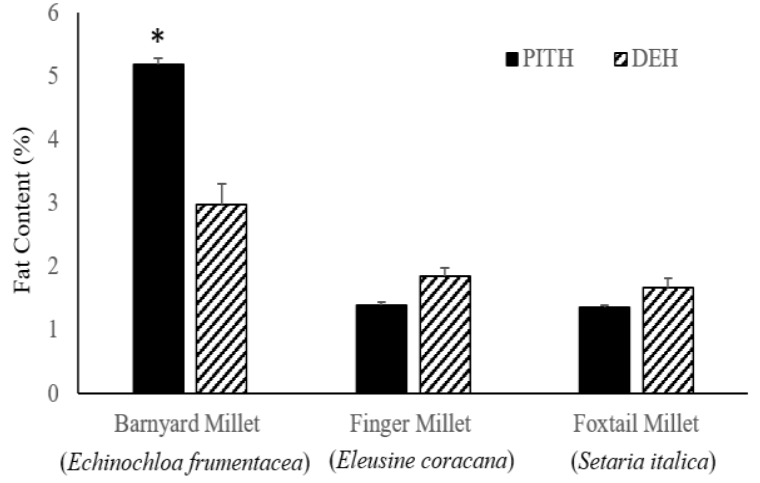

Fig.2. Fat content $(\%)$ of three minor millet species grown in Dehradun (DEH) and Pithoragarh (PITH) (cold semi-arid regions of Uttarakhand). The percentage of fat obtained by Soxhlet extraction of millet grains is represented as Mean $\pm \mathrm{SE}$ of triplicates. *Significantly different $(\mathbf{p}<0.05)$.

Table 1. Proximate Composition of Millet Species Grown at Cold Semi-Arid Regions.

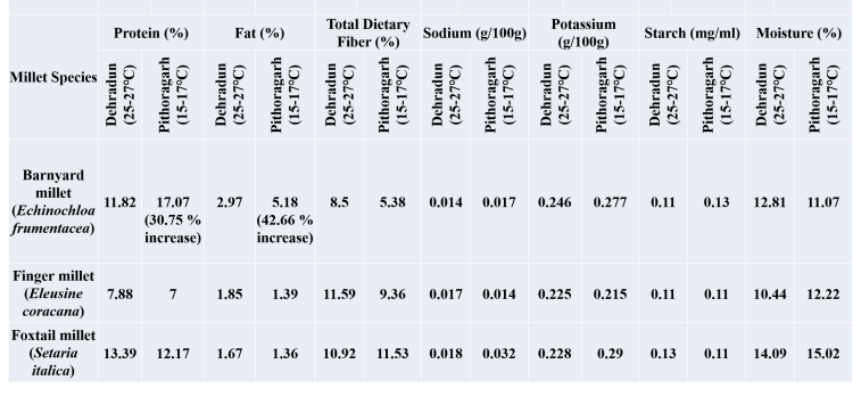

\section{Total Dietary Fibre Content}

The Total Dietary Fiber (TDF) content of millets in this study was determined without decortication (removal of pericarp) of grains, as the components which make up dietary fibre are mainly concentrated in the pericarp and the cell wall of the endosperm, giving it anti-oxidant properties [23].

Contrasting environments can affect the final composition of grains, including the dietary fiber concentration [29]. In this study, the millets grown at the colder semi-arid region of Pithoragarh $\left(15-17^{\circ} \mathrm{C}\right)$ exhibited decreased TDF content as compared to growth in the Dehradun region $\left(25-27^{\circ} \mathrm{C}\right)$ (Fig.3). In the Barnyard millet species, a $36.71 \%$ decrease in total dietary fiber content was recorded when grown at Pithoragarh compared to Dehradun. Similarly, the Finger millet species exhibited a $19.25 \%$ decrease in total dietary fibre content when grown at the comparatively colder region of Pithoragarh (15$\left.17^{\circ} \mathrm{C}\right)$. The difference between the total dietary fibre content of Foxtail millet when grown at Dehradun compared to Pithoragarh was negligible $(5.3 \%$ decrease in Dehradun). The TDF contents of the millet grains in this study fall close to or within the range of the TDF content reported in literature [23,24].

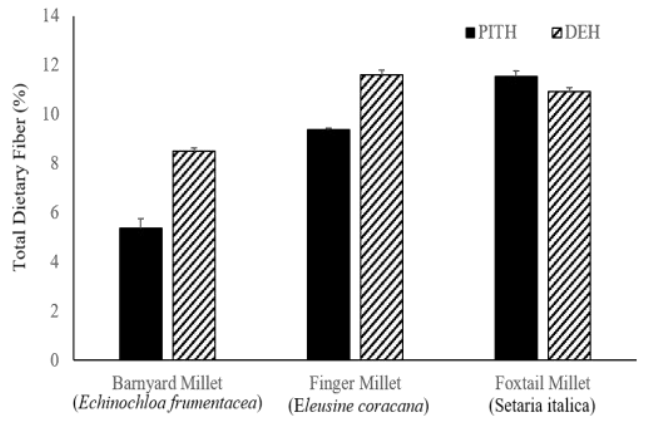

Fig.3. Total Dietary Fiber (TDF \%) present in three minor millet species from cold semi-arid regions of Dehradun (DEH) and Pithoragarh (PITH). A. Percentage of TDF was determined through an enzymatic assay (Sigma- TDF-100A 1KT). The graph represents Mean $\pm \mathrm{SE}$ of triplicates.

\section{Sodium and Potassium Content}

The sodium $\left(\mathrm{Na}^{2+}\right)$ and potassium $\left(\mathrm{K}^{+}\right)$levels present within the grains of the three millet species were analysed using a flame photometer. In the Foxtail millet species grown at Pithoragarh $\left(15-17^{\circ} \mathrm{C}\right)$, the level of sodium in the grains showed a $24.56 \%$ increase compared to growth at Dehradun $\left(25-27^{\circ} \mathrm{C}\right)$ (Fig.4a). Similar to sodium, the level of potassium in these Foxtail millet grains grown at Pithoragarh $\left(15-17^{\circ} \mathrm{C}\right)$, also displayed a $24.13 \%$ increase (Fig.4b). The Finger millet species did not display significant differences in sodium and potassium levels with growth in the colder region of Pithoragarh. However, there was a small increase in the level of sodium $(9.5 \%)$ and potassium (11.11\%) found in Barnyard millet grains grown at Pithoragarh $\left(15-17^{\circ} \mathrm{C}\right)$, compared to the Barnyard millet grown at Dehradun $\left(25-27^{\circ} \mathrm{C}\right)$. The sodium and potassium levels of the millet grains in this study were found to be similar to the sodium and potassium content reported earlier in literature [4].

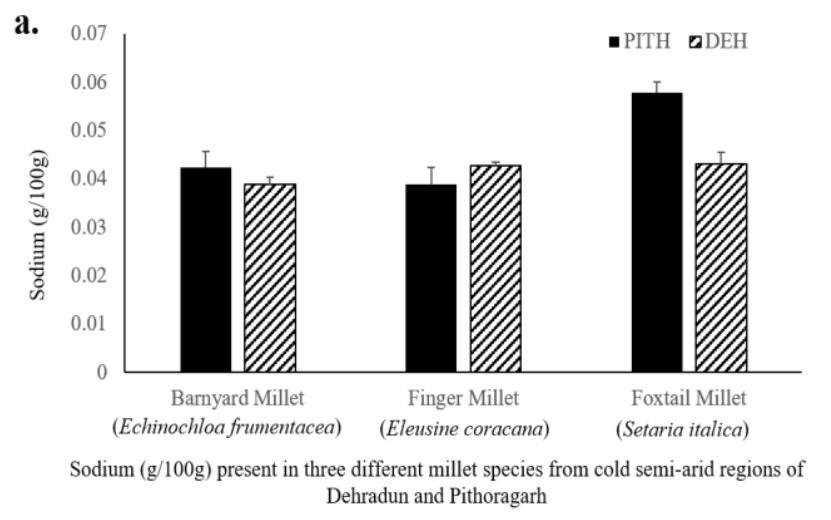


b.

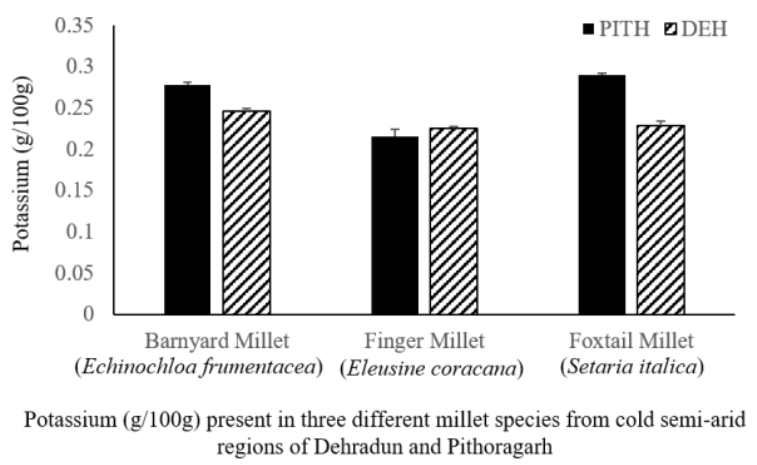

Fig 4. Sodium (a) and potassium (b) contents (g/100g) of three different millet species grown in the cold semiarid regions of Uttarakhand (Dehradun-DEH and Pithoragarh-PITH). The graph represents Mean \pm SE of triplicates.

\section{E. Starch and Moisture Content}

A comparative analysis of starch concentration in starch solutions of millet flour from all three millet species was carried out using Anthrone's reagent (Fig.5a). There was negligible difference in the starch concentration of millets from Pithoragarh $\left(15-17^{\circ} \mathrm{C}\right)$ compared to Dehradun $\left(25-27^{\circ} \mathrm{C}\right)$.

Experiments involving the determination of moisture content revealed no significant differences between populations of the three millet species grown at Pithoragarh $\left(15-17^{\circ} \mathrm{C}\right)$ compared to Dehradun $\left(25-27^{\circ} \mathrm{C}\right)$ (Fig. 5b). The starch and moisture contents of the three millet species used in this study are consistent with previously reported data from warm semi-arid regions $[8,24]$.

a.

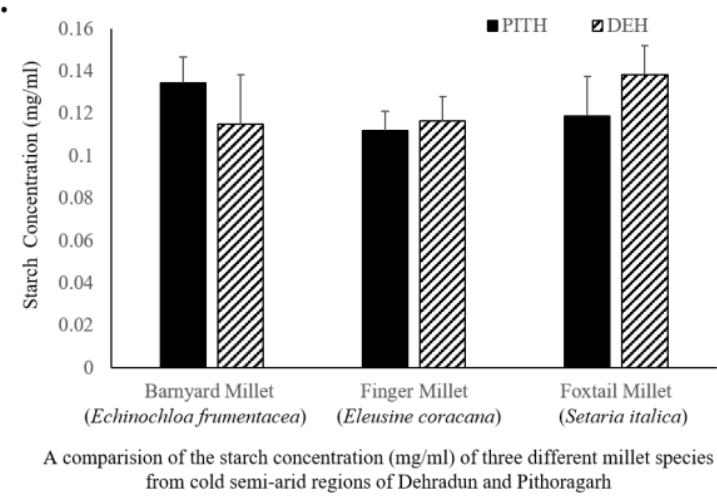

b.

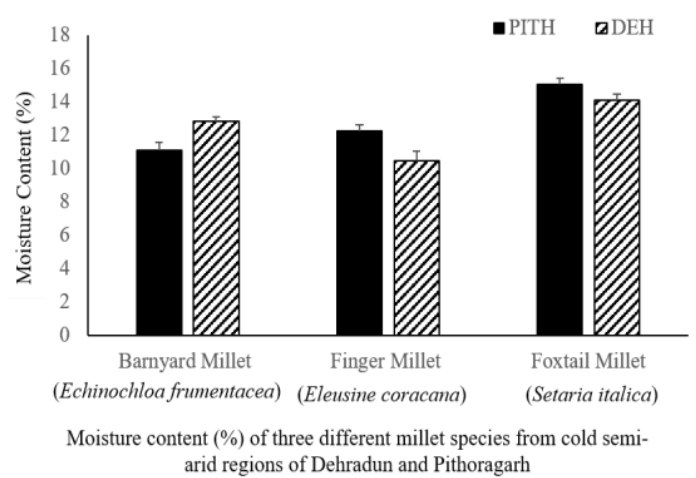

Fig.5. Comparative starch concentration $(\mathrm{mg} / \mathrm{ml})$ and moisture content $(\%)$ of three minor millet species grown in the cold-semi-arid regions of Uttarakhand (Dehradun-DEH and Pithoragarh-PITH), a. Starch concentration $(\mathrm{mg} / \mathrm{ml})$ of cold semi-arid region millets, determined using Anthrone's Reagent. b. Moisture (\%) in three different millet species from Dehradun (DEH) and Pithoragarh (PITH). The graphs are representative of values derived as Mean $\pm \mathrm{SE}$ of triplicates.

\section{CONCLUSION \& FUTURE SCOPE}

This study depicts the importance of nutritional research on minor millets, especially from regions that are geographically isolated and withstand extremes of temperature during growth. Here, the minor species, Barnyard millet, exhibited substantial increase in protein and fat contents when grown at 1514 masl. with cold temperatures of $15-17^{\circ} \mathrm{C}$, as opposed to growth at 640 masl with a temperature of $25-27^{\circ} \mathrm{C}$. Foxtail millet displayed higher sodium and potassium levels, and there was found to be a decrease in the Total Dietary Fiber (TDF) content with decrease in growth temperature for all three millet species analysed.

These results illustrate the existence of millet cultivars in these geographically and environmentally isolated regions, which may have increased or decreased levels of grain components due to differences in growth conditions, such as very low temperatures, as shown in this study. Although, continuous accessibility to such geographical regions is a limitation, further studies exploring the proximate composition of minor millets growing in such regions of extreme temperatures would reveal the ideal conditions of growth for maximum nutritional benefit. This may lead to finding new germplasm, and would improve the living standard of the rural population in these regions.

\section{ACKNOWLEDGEMENTS}

This work has been funded by the Department of Science \& Technology, Woman Scientist- Scheme A, Govt. of India.

The authors thank Prof. (Dr.) Kusum Arunachalam, HoD, Department of Environmental Sciences, School of Environment and Natural Resources (SENR), Doon University, Uttarakhand, India, for the use of their Kjeldalh Digestion and Distillation apparatus, as well as lab facilities including the Dietary Fibre Analysis System and muffle furnace.

\section{REFERENCES}

1. B. Dayakar Rao, K. Bhaskarachary, G. D. Arlene Christina, G. Sudha Devi, A. T. Vilas and A. Tonapi, "Nutritional and health benefits of millets," ICAR_Indian Institute of Millets Research (IIMR), Rajendranagar, Hyderabad, p. 112, 2017.

2. R. B. Singh, S. Khan, A. K. Chauhan, M. Singh, P. Jaglan, P. Yadav and L. R. Juneja, "Millets as functional food, a gift from Asia to Western World," In The Role of Functional Food Security in

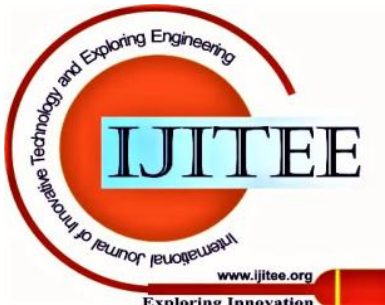




\section{Proximate Composition of Minor Millets from Cold Semi-Arid Regions}

Global Health, Academic Press, pp. 457-468, 2019.

3. S. Venkatesan and K. Sujatha, "Characterization of Barnyard Millet Cultivars using Seed Image Analysis," Seed Research, vol. 45(2), pp. $1-3,2018$.

4. J. R. N. Taylor and J. Kruger, "Millets. Encyclopedia of Food and Health," pp. 748-757, 2016.http://dx.doi.org/10.1016/B978-0-12384947-2.00466-9

5. P. B. Devi, R. Vijayabharathi, S. Sathyabama, N. G. Malleshi and V. B. Priyadarisini, "Health benefits of finger millet (Eleusine coracana L. ) polyphenols and dietary fiber: a review," Journal of food science and technology, vol. 51(6), pp. 1021-1040, 2014.

6. S. K. Kumari and B. Thayumanavan, "Characterization of starches of proso, foxtail, barnyard, kodo, and little millets," Plant Foods for Human Nutrition, vol. 53(1), pp. 47-56, 1998.

7. International Crop Research Institute for the Semi-arid Tropics (ICRISAT), 2007 annual report, http://test1icrisatorg/publications/Ebooksonline publications/annual report-2007pdf [2007]. and S. R. Beedu, "Proximate, mineral composition and antioxidant activity of traditional small millets cultivated and consumed in Rayalaseema region of south India," Journal of the science of food and agriculture, vol. 98(2), pp. 652-660, 2018.

9. G. Ravindran, "Studies on millets: Proximate composition, mineral composition, and phytate and oxalate contents," Food Chemistry, vol.

10. P. Cunniff, "Official methods of analysis of aoac international," Journal of AOAC International, vol. 80(6), p 127A, 1997.

11. G. W. Latimer, "Official methods of analysis of AOAC International (No. 543/L357)," AOAC international, 2012.

12. AOAC, "Official Methods of Analysis." Official Method 2001.11, 2005.

13. F. Soxhlet, "Dinglers," Polyt. J, vol. 232, p. 461, 1879.

14. AOAC, "Official Methods of Analysis," Official Method 930.09, 2005.

15. C. Paquot, "Standard methods for the analysis of oils. Elsevier Science," 1979.

16. AOAC, "Official Methods of Analysis," Official Method 985.29, 1997.

17. AOAC, "Official Methods of Analysis." Official Method 969.23 2005.

18. M. Bwai, M. Afolayan, D. Odukomaiya and O. Abayomi, "Proximate composition, mineral and phytochemical constituents of Eleusine coracana (finger millet)," International Journal of Advanced Chemistry, vol. 2(2), pp. 171-174, 2014.

19. D. L. Morris, "Quantitative Determination of Carbohydrates With Dreywood's Anthrone Reagent," Science (Washington), vol. 107, pp. 254-255, 1948.

20. AOAC, "Official Methods of Analysis," Official Method 935.29, 1997.

21. Vinoth and R. Ravindhran, "Biofortification in millets: a sustainable approach for nutritional security," Frontiers in plant science, vol. 8 , p.29, 2017.

22. C. W. Wrigley, H. Corke, K. Seetharaman and J. Faubion, "Encyclopedia of food grains," (Eds.), Academic Press, 2015.

23. S. O. Serna-Saldivar and J. Espinosa-Ramírez, "Grain structure and grain chemical composition," In Sorghum and Millets, AACC International Press, pp. 85-129, 2019.

24. R. Ugare, B. Chimmad, R. Naik, P. Bharati and S. Itagi, "Glycemic index and significance of barnyard millet (Echinochloa frumentacae) in type II diabetics," Journal of food science and technology, vol. 51(2), pp. 392-395, 2014

25. M. Cooper, D. R. Woodruff, I. G. Phillips, K. E. Basford, and A. R. Gilmour, "Genotype-by-management interactions for grain yield and grain protein concentration of wheat," Field Crops Research, vol. 69(1), pp. 47-67, 2001

26. G. Karimzadeh, D. Francis and M. S. Davies, "Low temperatureinduced accumulation of protein is sustained both in root meristems and in callus in winter wheat but not in spring wheat," Annals of of some varieties of ragi (Eleusine coracana)," Indian Journal of Nutrition and Dietetics, vol. 7, pp. 80-84, 1970.

28. M. S. Pore and N. G. Magar, "Nutritive value of hybrid varieties of finger millet," Indian J. Agric. Sci., vol.47, p. 226, 1977.
8. K. Vali Pasha, C. V.Ratnavathi, J. Ajani, D. Raju, S. Manoj Kumar 39(1), pp. 99-107, 1991. Botany, vol. 85(6), pp. 769-777. 2000.

27. Y. G. Deosthale, V. Nagarajan and K. C. Pant, "Nutrient composition

29. M. Miranda, A.Vega-Gálvez, E. A. Martínez, J.López, R. Marín, M. Aranda and F. Fuentes, "Influence of contrasting environments on seed composition of two quinoa genotypes: nutritional and functional properties," Chilean journal of agricultural research, vol. 73(2), pp.108-116, 2013.

\section{AUTHOR'S PROFILE}

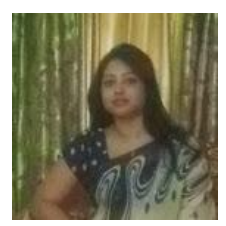

Madhulika Esther Prasad

Ph.D. Scholar \& DST Project Principal Investigator (PI), Department of Biotechnology, Graphic Era (deemed to be University), Email address: esthermadhu@gmail.com; esthermadhu.bio@geu.ac.in Phone: 91-8449355973

\section{Education:}

- Phd in Biotechnology (2017-Present) DST Woman Scientist Project Department of Biotechnology, Graphic Era (deemed to be University), 566/6, Bell Road, Clement Town, Dehradun, Uttarakhand India.

- MSc in Biology (Research) (2007-2010), Department of Biology, Dalhousie University, Halifax, NS Canada

- B.Tech. in Biotechnology, SHUATS, Allahabad, India.

Research Area: Cereal Biotechnology

DST Woman Scientist-Scheme A Project Title: Millets as a Component of Diet Diversity to Alleviate Malnutrition.

Publications:

Google

Scholar

Citations

(https://scholar.google.co.in/citations?user=gSC -NMAAAAJ\&hl=en)

- $\quad$ Prasad ME, Schofield A, Lyzenga W, Liu H, Stone SL. (2010). Arabidopsis RING E3 ligase XBAT32 regulates lateral root production through its role in ethylene biosynthesis. Plant Physiol.,153(4):1587-96. (SCI; IF-6.841)

- $\quad$ Prasad ME, Stone SL. (2010). Further analysis of XBAT32, an Arabidopsis RING E3 ligase, involved in ethylene biosynthesis. Plant Signal Behav., 5(11). (SCI; IF-2.2)

- $\quad$ Ramu T, Prasad ME, Mishra A, ThomassinJL, Rainey JK and Thomas NA. (2013). A novel C-terminal region within the multicargo type III secretion chaperone CesT contributes to effector secretion.J Bacteriol., 195(4):740-56.(SCI; IF-4.573)

- Thomas NA, Ma I, Prasad ME, Rafuse C. (2012). Expanded Roles for Multicargo and Class 1B Effector Chaperones in Type III Secretion.J Bacteriol., 194(15):3767-73. (SCI; IF-4.573)

- Madhulika Esther Prasad, Ayyanadar Arunachalam, Pankaj Gautam (2020). Millet: A Nutraceutical Grain that Promises Nutritional Security. Ecology, Environment and Conservation. (Accepted Manuscript; Scopus, ISSN: 0971-765X)

- Madhulika Esther Prasad, Lok Man Singh Palni, Pankaj Gautam (2020). Millets for Combating Malnutrition in Rura Areas. Science and Technology in Rural Areas. (Accepted Book Chapter)

- Madhulika Esther Prasad, Ishita Joshi, Navin Kumar, L.M.S. Palni (2019). Characterization of Nutritional and Genetic Diversity in Millets of Uttarakhand. American Council for Medicinally Active Plants.

Awards\& Achievements:

- Invited Speaker at the International Plant Biology conference (2010) of the Canadian Society of Plant Biologists (CSPB) in Montreal, Canada.

- Invited Speaker at the International Plant Biology conference (2009) of the American Society of Plant Biologists (ASPB) at Simon Fraser University, British Columbia, Canada.

- $\quad$ Recipient of competitive travel grant from Canadian Society of Plant Biologists (CSPB) in 2010.

- Awarded Research Scholarship from Natural Sciences and EngineeringResearch Council of Canada (NSERC) for a duration of 2 years.

$\begin{array}{lr}\text { - Awarded } & \text { Research } \\ \text { Scholarship } & \text { from } \\ \text { Department of Postgraduate }\end{array}$ 
studies, Dalhousie University, Canada.

- Two time recipient of the The Patrick F. Lett Graduate Student Funding at Dalhousie University, Canada.

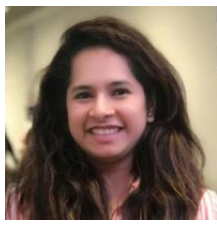

Name: Ishita Joshi

Chemical Analyst, DTS Food Assurance, Melbourne, Australia

Education:

- MTech. in Food Science and Technology, RMIT University, Melbourne, Australia

- B.Tech. in Biotechnology, Graphic Era (deemed to be University), Dehradun, India

Research:

Research presented in International conferenceof American Council for Medicinally Active Plants (ACMAP- 2019)

- Madhulika Esther Prasad, Ishita Joshi, Navin Kumar, L.M.S Palni (2019). Characterization of Nutritional and Genetic Diversity in Millets of Uttarakhand. American Council for Medicinally Active Plants.

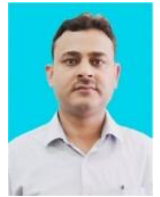

Prof. Navin Kumar, PhD, NET

Head, Department of Biotechnology, Graphic Era Deemed to be University, Dehradun

Contact: 7417325585

E. Mail: navinkumar.bt@geu.ac.in

Field of Interest \& Area of Research: Molecular Biology

\& Genetics

Awards/Achievements/Recognitions:

- PhD theses supervised: 06

- $\quad$ Research project completed: 01

- Patents Filed: 03; PCT published: 02

- Gene Bank Submission: 28; Book Chapters: 03

- Scientific events organized

Conference/Seminar/Workshop attended: 35

- Editor, Biotechnology International Journal (ISSN 0974 1453)

- Mentor on DST Women Scientist Project: 'Millets as a component of diet diversity to alleviate malnutrition.' [Sanctioned Amount: INR 20.00 Lakhs; Duration: 03 Years (2018-2020)].

- Founder of BioPRENEURS' Club in the University in year 2016.

Awards \& Fellowships-

- DRDO-JRF/SRF (2004-2009) from Defence Research \& Development Organization, Ministry of Defence, Govt. of India for pursuing Ph.D

- UGC- SAP Project Fellowship (2003-2004) in the University of Rajasthan, Jaipur, India.

- $\quad$ Received Young Scientist Award-2015 in $9^{\text {th }}$ Uttarakhand State Science \& Technology Congress

- Received University Research Performance Awards for the years 2012, 2015 and 2019 in Graphic Era Deemed to be University, Dehradun.

Other Administrative Responsibilities:

- Head, Department of Biotechnology.

- Member, Academic Council, Graphic Era Deemed to be University (GEU), Dehradun, UK, India

- Member, Board of Studies, GEU.

- Assistant Coordinator IPR Cell, GEU.

- Member Research and Consultancy Board, GEU

- Member, Institutional Biosafety Committee, approved by DBT, Govt. of India.

- Member in internal audit teams for NBA, NAAC, UGC and AICTE compliances.

$>\quad$ Research Publications (Top 10 publications):
(Total publications: 38)

https://scholar.google.com/citations?hl=en\&user=LVW4NooAA AAJ\&view op=list works\&sortby=pubdate); Web of Science Researcher ID- AAH-6271-2020

Best 10 Publications:

1. Payal Gupta, Anshika Rastogi, Anuja Bhardwaj, Kshipra Misra, Navin Kumar (2018). 'Antagonistic properties of methanolic leaf extract of Elaeocarpus sphaericus against growth, germ tube formation, adhesion and biofilm of Candida species.' Indian Journal of Pharmaceutical Sciences 80 (5): 949-954 (Impact factor- $\mathbf{0 . 6 3 4}$ as per JCR-2019). DOI: $10.4172 /$ pharmaceutical-sciences.1000443

2. Gupta Payal, Gupta Sonam, Sharma Meenakshi, KumarNavin, Pruthi Vikas, Poluri Krishna Mohan (2018). 'Effectiveness of phyto-active molecules on transcriptional expression, biofilm matrix and cell wall components of Candida glabrata and its clinical isolates.' ACS Omega; 3:12201-12214 (Impact factor: $\mathbf{2 . 5 8 4}$ as per JCR-2019). DOI: $10.1021 /$ acsomega.8b01856

3. Sakshi Painuli, Swati Joshi, Anuja Bhardwaj, Ramesh Chand Meena, Kshipra Misra, Nishant Rai, Navin Kumar(2018). 'In-vitro antioxidant and anticancer activities of leaf extracts of Rhododendron arboreum and Rhododendron campanulatum from Uttarakhand region of India.' Pharmacognosy Magazine; 14 (57): S294-303 (Impact Factor-1.26 as per JCR-2019)

DOI: $10.4103 /$ pm.pm_15_18

4. Anuja Bhardwaj, Payal Gupta, Navin Kumar, Jigni Mishra, Ajai Kumar, Rakhee Rajput, Kshipra Misra (2017). 'Lingzhi or Reishi Medicinal Mushroom, Ganoderma lucidum (Agaricomycetes), Inhibits Candida Biofilms: A Metabolomic Approach.' International Journal of Medicinal Mushroom; 19 (8): 685-696 (Impact factor-1.423as per JCR-2019). DOI: 10.1615/IntJMedMushrooms.2017021225

5. Payal Gupta, Ramesh C Meena, Navin Kumar(2017). 'Functional analysis of selected deletion mutants in Candida glabrata under hypoxia.' 3 Biotech; 7 (193): 1-9. (Impact factor- $\mathbf{1 . 7 8 6}$ as per JCR-2019). DOI: $10.1007 / \mathrm{s} 13205-017-0821-7$

6. Payal Gupta, Reshmi Chanda, Nishant Rai1, V. K. Kataria, Navin Kumar (2016). 'Antihypertensive, Amlodipine Besilate Inhibits Growth and Biofilm of Human Fungal Pathogen Candida.' Assay and Drug Development Technology; 14 (5):291-97 (Impact factor -1.420 as per JCR-2019). DOI: $10.1089 /$ adt.2016.714

7. Gupta P, Nath S, Meena RC, Kumar N (2014). 'Comparative effects of hypoxia and hypoxia mimetic cobalt chloride on in vitro adhesion, biofilm formation and susceptibility to amphotericin B of Candida glabrata.' Journal de Mycologie Medicale; 24(4) : e169-77 (Impact Factor- 1.479 as per JCR-2019). DOI: 10.1016/i.mycmed.2014.08.003

8. Meena RC, Kumar N, Nath S, Chakrabarti A (2012). 'Homologous recombination is activated at early time points following exposure to cobalt chloride induced hypoxic conditions in Saccharomyces cerevisiae. 'Indian Journal of Microbiology; 52 (2):209-214 (Impact factor -1.533as per JCR-2019). DOI: $10.1007 / \mathrm{s} 12088-011-0195-1$

9. Kumar N, Meena RC, Chakrabarti A (2011). 'Overexpression of YLR162W inhibits cell proliferation and renders cells susceptible to the hypoxia mimetic agent Cobalt chloride in Saccharomyces cerevisiae.' Indian Journal of Microbiology; 51(2): 206-211 (Impact factor 1.533as per JCR-2019). DOI: $10.1007 / \mathrm{s} 12088-011-0132-3$

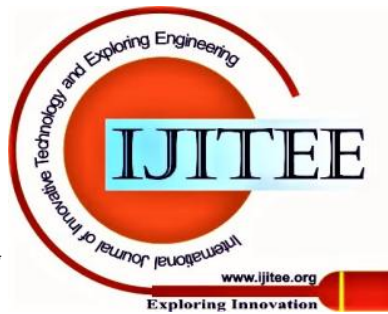


Name: Pankaj Gautam

Associate Professor \& Hod, Life Sciences, Graphic Era

(deemed to be University)

Educational Qualification: Ph. D. (Biotechnology), NET

Area Of Academic Interest: Microbial Pathogenesis \&

Research Publication:

- 2018; In vitro immunomodulatory potential of Artemisia indica Willd. in chicken lymphocytes, Pushpa Ruwali, Tanuj Kumar Ambwani, Pankaj Gautam, 11 (1), 80.

- 2017; In vitro antioxidative potential of Artemisia indica willd, P. Ruwali, T. K. Ambwani, Pankaj Gautam, Indian J. Anim. Sci 87 (11), 1326-1331.

- 2017;Cerebrospinal Fluid (CSF) Analysis for Herpes Simplex Virus (HSV) Detection by Real-Time Polymerase Chain Reaction, Pankaj Gautam, Narotam Sharma, Sakshi Tripathi, Shivangi Shukla, Shivam Nagrath, Indian Journal of Genetics and Molecular Research 6 (1).

- 2016; Anticancer drugs as prospective efflux pump inhibitors for Salmonella typhi produce conflicting results in in silico and in vitro studies, Pranjali Gupta, Pankaj Gautam, Nishant Rai, International Journal of Pharmacy and Pharmaceutical Sciences, 8 (12).

\section{PATENTS}

- Indian Patent Application 1500/DEL/2014: Primers Probes And Test Kit For The Detection Of Salmonella Priority date 05/Jun/2014 Filed Complete on 04/Jun/2015 Inventors - Pankaj Gautam, Navin Kumar, Nishant Rai, Ashish Thapliyal Also filed PCT on 05/Jun/2015 - PCT/IB2015/000859 (ISA - IN).

- Indian Patent Application 1625/DEL/2014: A Phytochemical Rich Herbal Extract And Process Of Extraction Thereof Priority date - 16/Jun/2014 Filed Complete on 16/Jun/2014 Inventors Navin Kumar, Pankaj Gautam, Kshipra Misra, Raj Kumar Tulswani, Payal Gupta, Swati Joshi, Sakshi Painuly Also filed PCT on 16/Jun/2015 - PCT/IB2015/000950 (ISA - IN). 